\title{
The Architecture of Alveolar Capillaries in the Lungs of Bactrian Camels (Camelus bactrianus)
}

\author{
Arquitectura de los Capilares Alveolares de Pulmones de Camellos Bactrianos (Camelus bactrianus)
}

\author{
Xiaohua Du'; Xia Liu² \& James Blackar Mawolo
}

DU, X.; LIU, X. \& MAWOLO, J. B. The architecture of alveolar capillaries in the lungs of Bactrian camels (Camelus bactrianus). Int. J. Morphol., 38(6):1779-1785, 2020.

SUMMARY: The Bactrian camel, which is native to China and Mongolia, is large in size and is an even-toed ungulate species. The double humps on the Bactrian camel back differentiate it from the dromedary camel, which has a single hump. This species has adapted to unsuitable conditions (lack of food and water) in the Gobi Desert and is advanced in unique anatomical and physiological characteristics during a prolonged evolution period. Several studies have been conducted on the anatomical features of the Bactrian camel, but none have given attention to the alveolar capillaries of the Bactrian camel lung. Therefore, the current study aims to explore the architecture of the alveolar capillary in the Bactrian camel lung and further explain the mechanism of blood flow in its lung. The current study extracted and examined the architecture of the alveolar capillary in the lung of the Bactrian camel (Camelus bactrianus) and further explained the mechanism of blood flow by performing lung casting and replica scanning electron microscopy methods. The reports showed that the resources of the alveolar-capillary originated from the capillaries of the subpleural space or interlobular septulum, sometimes originating from the precapillary arterioles or directly from the terminal arterioles. The alveolar capillaries anastomosed and formed a single layer of dense, basket-like network surrounding the alveolus. The mash diameter of the alveolar-capillary network was larger than that of the capillary, and the appearance of the mash was oval and elliptical. Many of the collapsed alveolar-capillary networks were found in the alveolar microvascular architecture in the lung of the Bactrian camel. The study found that, due to many collapsed alveoli in the Bactrian camel lung, the disproportional pressure between the pulmonary alveoli induced less imbalance of blood flow in the alveolar capillary, which affected the gas exchange efficiency. Therefore, the function of the anastomosing capillary branch was likely to regulate the blood flow between the alveolar-capillary network.

KEY WORDS: Bactrian camel, lung, scanning electron microscope (SEM), alveolar capillary, blood flow.

\section{INTRODUCTION}

The Bactrian camel is a special ruminant that still lives in a wild state in the Gobi Desert and nearby dry steppe (grassland) of Central Asia, especially China and Mongolia. The two-humped back of this species remains a differentiating feature from other camels. A Bactrian camel weighs between 600 and $1000 \mathrm{~kg}$ (1,320 to 2,200 lb) and stands over $2 \mathrm{~m}$ (7 ft) tall.

The architecture of the microvasculature of the lungs in humans and other mammals has been studied by transmission electron microscopy (TEM) and scanning electron microscopy (SEM) (Weibel \& Gomez, 1962; Smith \& Campbell, 1976; West et al., 1977; Hijiya \& Okada, 1978; Kendall \& Eissmann, 1980; Guangqi et al,. 1981; Fujii et al., 1981; Rui et al., 1993; Yu, 1997a, 1998a); However, studies on the microvasculature of the lungs of large mammals, especially the Bactrian camel, are extremely limited. Yu et al. (2004) studied the architecture of the subpleural microvasculature of the lung in the Bactrian camel but did not mention the architecture of the alveolar capillary of the lung. Buchacker et al. (2019) reported that the alveolarcapillary network $(\mathrm{ACN})$ in newborn mice has double capillary layers that are connected. An arteriole path linking the venule was extracted and straightened to permit crosssectional visualization within a plane. This action enables the structural characterization that erythrocytes process through the ACN. Another study, He et al. (2019) conducted on bronchus-associated lymphoid tissue (BALT) in Bactrian camels documented that the lungs are characterized by various regions. The cranial lobe, which is one of the regions, was

\footnotetext{
${ }^{1}$ College of Veterinary Medicine, Gansu Agricultural University, Lanzhou City, Gansu Province, 730070, People's Republic of China.

${ }^{2}$ College of Life Science and Technology, Gansu Agricultural University, Lanzhou City, Gansu Province, 730070, People's Republic of China.
} 
narrow, while the caudal lobe was well advanced (nearly four times the size of the cranial lobe), and the accessory appeared smaller than the cranial lobe. The bronchial tree containing a tracheobronchial branch has a system of the dorsal, ventral, lateral, and medial bronchioles. Johnson et al. (2014) explained that the increase in age could increase the median alveolar surface area; likewise, the age decrease could cause a lower median alveolar surface area. The point of linear intercept also increases as age advances within each lung of the horse, and the surface of the alveolar area was reported to be higher than the endothelial surface area. Meanwhile, studies conducted on the human lung explained that the alveolar and its surface areas play an essential role in gas exchange between air and blood, which aids in increasing lung size (Weibel \& Gomez). The conductive zone elements show a polar orientation in the human lung. However, there are extremely limited reports on the architecture of alveolar capillaries in the lungs of Bactrian camels. Therefore, lung casting and replica scanning electron microscopy methods were applied to extract and examine the architecture of alveolar-capillary lungs and the adaptability to drought and arid environments in the Bactrian camel.

\section{MATERIAL AND METHOD}

Animals and setting. Before being sacrificed, the animals were fed. These animals were pulled out of their housing area one after another by trained animal care-takers and moved to the slaughterhouse of the Right Alasan Banner Food Company in the Inner Mongolia Autonomous Region, China. The whole lungs of 6 adult and healthy Bactrian camels (4 males and 2 females) were collected from all animals involved in this study. The six adult and healthy Bactrian camels were divided into two groups: 4 males and 2 females. Only camel without diseases were involved in this study. The procedures applied during sampling were fully reviewed and approved by the Animal Ethical and Welfare Committee of Gansu Agricultural University (GAU-AEW-2019-0021).

Animal Sacrifice. A $10 \%$ ABS solution of butanone (ternary copolymer of acrylonitrile, butadiene, and styrene) Chaoyou (1988) was injected immediately through the pulmonary artery. Samples were taken from sacrificed Bactrian camels on two (2) occasions (for two weeks). During each collection period, samples were extracted from Bactrian camel lungs. Six (6) Bactrian camels were sampled: 4 males (5 years old) and 2 females ( 7 years old). The entire lung was sampled by trained personnel.

Tissue samples weighing 1-2 g were collected aseptically from various lung regions by applying medical instruments such as scalpels, forceps, and scissors. Later, these samples were placed in running water to remove the ABS solution. The researchers were aware that there might be crosscontamination; therefore, the samples were taken to a nearby room and examined on a table disinfected by trained personnel. These personnel were protected and wore face masks, gloves and donned gowns. The collected and labeled samples were placed in plastic bags in a cooler containing ice blocks and sent to the laboratory. The samples were transported within 2 hours to the laboratory and kept at $-80^{\circ} \mathrm{C}$ until further examination. All efforts were applied to minimize animal pain and the usage of animals.

\section{Specimen Examination by Scanning Electron Microscopy} (SEM). Proper small pieces of specimens were collected from different extracted lung lobes, and were then cut into SEM specimens and placed into $10 \%$ hydrochloric acid at room temperature for 2 weeks. Later, they were washed in flowing water in a net box slowly. Then, the residues were washed out, and the casts were selected, dried and bumble-coated with gold-palladium and examined under a Hitachi S520 scanning electron microscope.

Statistical analysis. Data analysis was performed using SPSS for Windows version 7. T-test statistical analysis was considered.

\section{RESULTS}

The decomposed casts of the alveolar capillary showed a complex triple-dimensional network completely; however, there were no evident differences among camel lungs or lung lobes.

Supply of alveolar-capillary (Table I). The resources of the Bactrian camel alveolar capillaries were rich and they originated from the capillaries of the subpleural space or interlobular septulum, sometimes from the precapillary arterioles or the terminal arterioles directly (Figs. 1, 2 and 3). It was often observed that one alveolar capillary network was supplied by two or three kinds of capillary sources simultaneously. Under SEM, there was a representative stretch pattern when the precapillary arterioles gave off capillaries to form one alveolar capillary network (Fig. 4). The precapillary arteriole extended along the entrance of the alveolus with a circular line and gave off branches. These branches spread forward to the bottom of the alveolus and communicated with each other to form the alveolar-capillary network. The alveolar-capillary networks were collected into the postcapillary venules at the bottom of the alveolus, which was drained by the collected venule. 
Table I. Supply of alveolar-capillary in different mammals.

\begin{tabular}{ll}
\hline Experimental objects & Supply of alveolar-capillary \\
\hline Human & Subpleural or interlobular septulum capillary; branch of the precapillary arteriole. \\
Dog & Branch of the precapillary arteriole. \\
Monkey & Branch of precapillary arteriole; a capillary branch of terminal arteriole directly. \\
Mouse & Sub pleural or inter lobular septulum capillary \\
Labora tory rabbit, pika & Same as humans. \\
Bactrian camel & Subpleural or interlobular septulum capillary; branch of precapillary arteriole; a capillary branch of \\
& terminal arteriole directly. \\
\hline
\end{tabular}

As observed in the table, there exist some similarities and differences in the alveolar-capillary among humans and these mammals.

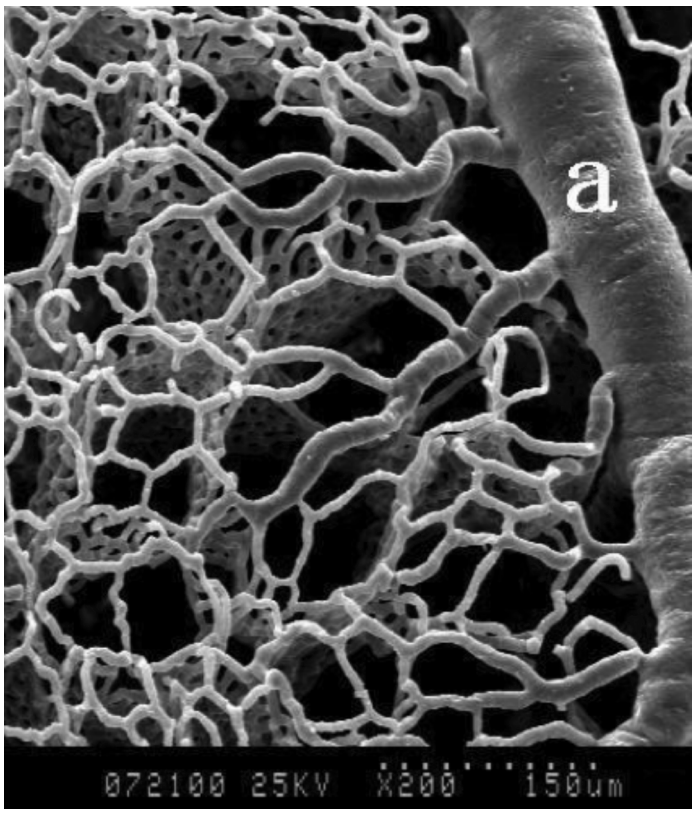

Fig. 1 Supply of alveolar-capillary. *The sub-pleural capillaries extended into the alveolar capillaries directly.

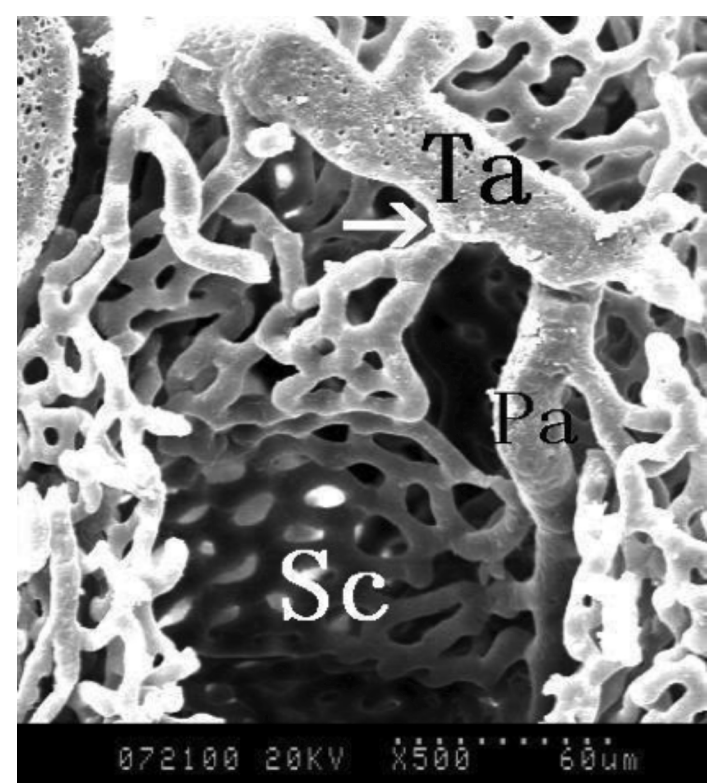

Fig. 3 Supply of alveolar-capillary. *The arrow (Æ) showed the alveolar-capillary originated from the terminal arteriole (Ta) directly.

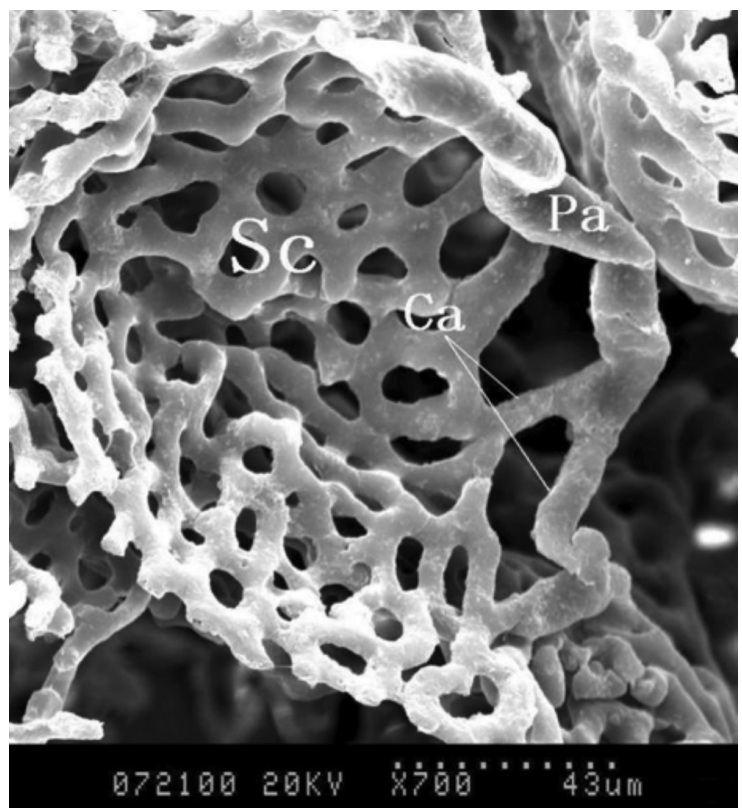

Fig. 2 Supply of alveolar-capillary. *The precapillary arteriole (Pa) gave off the capillary branches $(\mathrm{Ca})$ to form the alveolarcapillary network $(\mathrm{Sc})$. *The precapillary arteriole was curved in process.

The precapillary arterioles were curved in process, which seemed to be squeezed or to have extensive space.

The architecture of the peculiarity alveolar capillary network. The alveolar-capillary network displayed the three-dimensional architecture of pulmonary alveolar-capillary under low power SEM, in which there were large numbers of the alveolar cluster that showed a honeycombed configuration and arterioles or venules penetrating the alveolar interspace (Fig. 5).

In the architecture of the alveolar capillary in the Bactrian camel, the capillaries of the normal alveolus extended completely and formed the alveolar-capillary network, which is plump and smooth in appearance. Meanwhile, there were many alveolar capillaries that shrank up and therefore caused the collapse of these alveoli. Compared with the normal alveoli, the collapsed alveoli showed differences in the caliber and plump degree of the alveolar lumina. 


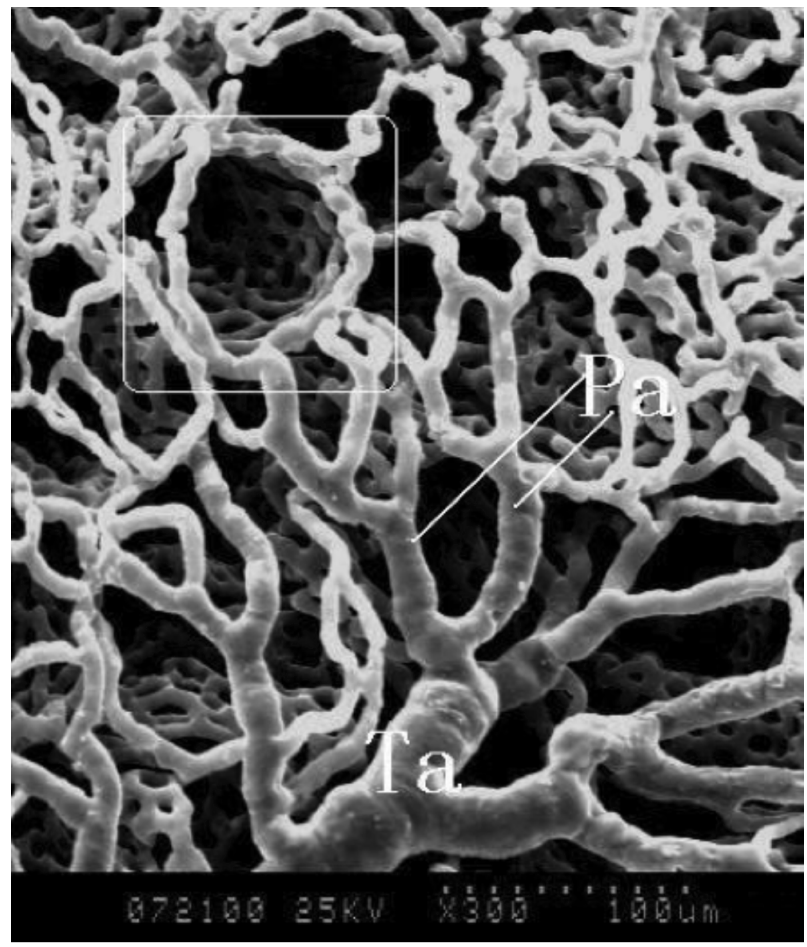

Fig. 4 Supply of alveolar-capillary. *The rectangle (?) showed the stretch pattern of the precapillary arterioles $(\mathrm{Pa})$ extending into the alveolar-capillary.

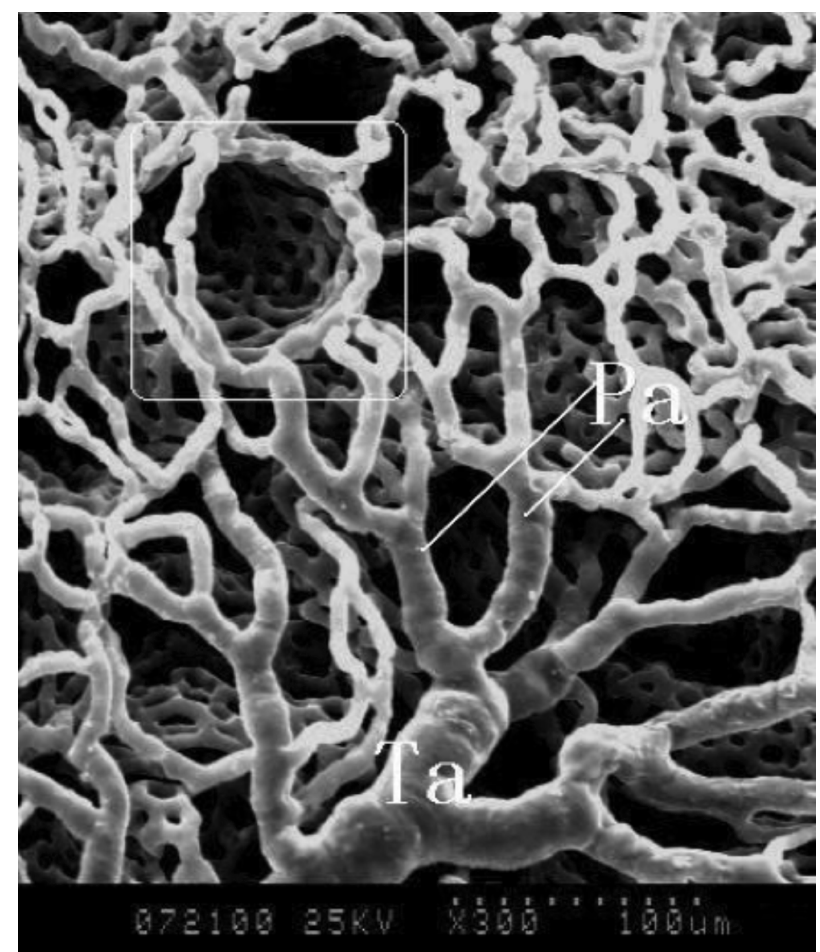

Fig. 5 The alveolar cluster capillary network arranged in honeycombed patterns. *The star $(*)$ showed the collapsed alveoli. The black line showed the range of one normal capillary network (Sc).
The current SEM observation on alveolar-capillary corrosion casts showed that a sort of capillary anastomosing branch connected the alveolar-capillary ring adjacently. This kind of anastomosing branch was commonly given off from one point of the capillary ring located at the entrance of the alveolus and curved on the entrance of the alveolus with the "Y" type to communicate with the other points of the capillary rings of the alveoli adjacently. Due to a lack of description by previous studies, these vessels are referred to as the "Y-type anastomosing branch" in the current study (Fig. 6).

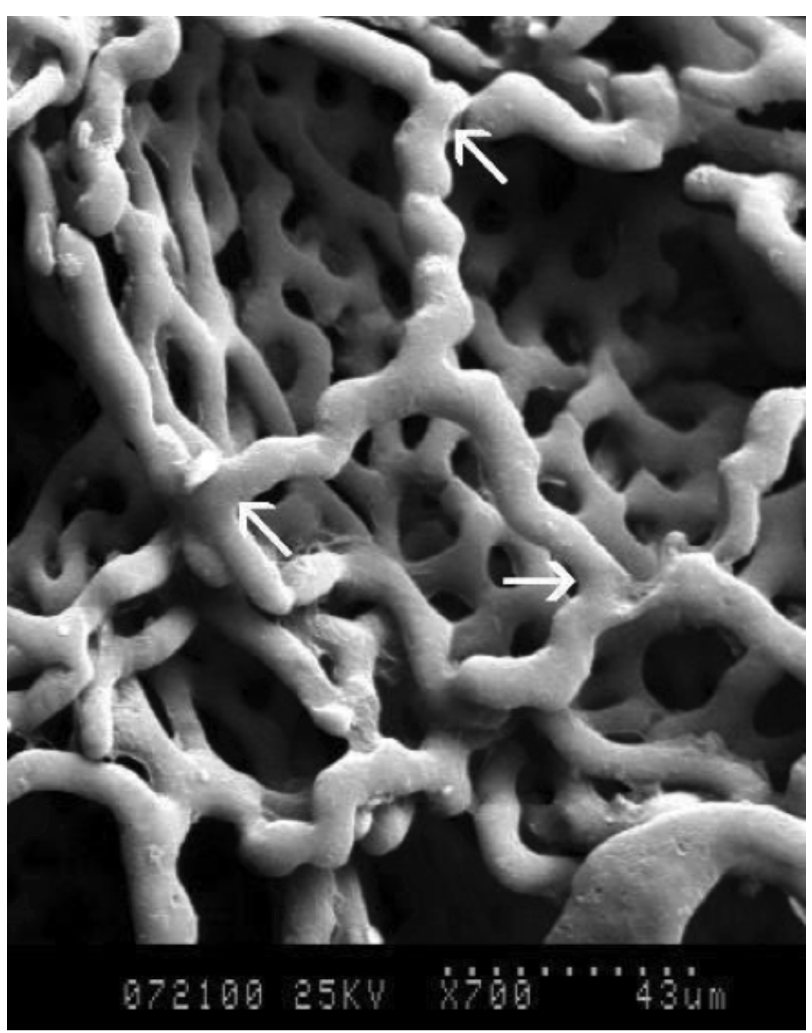

Fig. 6 Capillary anastomosing branches connecting alveolar capillary network adjacently. *The arrow $(\neq)$ showed the joint of the anastomosing branches with an alveolar-capillary ring.

Peculiarity surface of the alveolar-capillary cast. There were no circular-diagonal smooth muscle cell imprints on the surface of the alveolar capillaries, which were smoothfaced. The endothelial nuclei oval imprints appeared on the surface of the alveolar-capillary casts, which were arranged longitudinally along the microvasculature (Figs. 7 and 8).

The alveolar capillaries were relatively uniform in diameter, all of which were bulged in flat form and plump. Their diameters ranged from $4 \mathrm{~mm}$ to $8 \mathrm{~mm}$ (Table II), and the capillaries communicated with one another to form a single layer of the basket-like network surrounding the 
Table II. Diameters of alveolar-capillary and mesh of capillary network (mm).

\begin{tabular}{llcc}
\hline Regions & Capillary & Ribbon width of mesh & Minimum width of mesh \\
\hline Right accessory lobe & $6.87 \pm 0.94$ & $8.41 \pm 1.18$ & $5.01 \pm 0.94$ \\
Right apical lobe & $6.73 \pm 1.02$ & $9.17 \pm 2.13$ & $4.86 \pm 0.76$ \\
Left diaphragmatic lobe & $6.92 \pm 1.05$ & $8.93 \pm 2.07$ & $4.74 \pm 0.84$ \\
Left middle lobe & $6.45 \pm 0.79$ & $8.35 \pm 1.70$ & $4.46 \pm 1.08$ \\
Total** & $6.74 \pm 0.95$ & $8.72 \pm 1.77$ & $4.77 \pm 0.91$ \\
\hline
\end{tabular}

* Fifty capillaries and thirty meshes were measured in each lung lobe.

** There was no evident difference among lung lobes on the t-test $(\mathrm{P}>0.05)$.

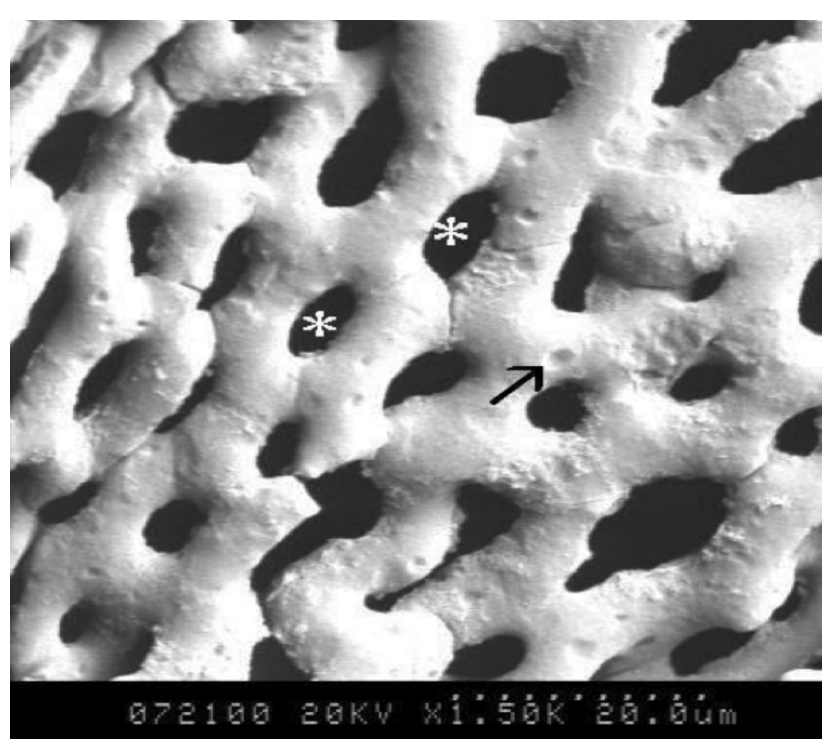

Fig. 7 The smooth muscle cells on the surface of the alveolarcapillary.

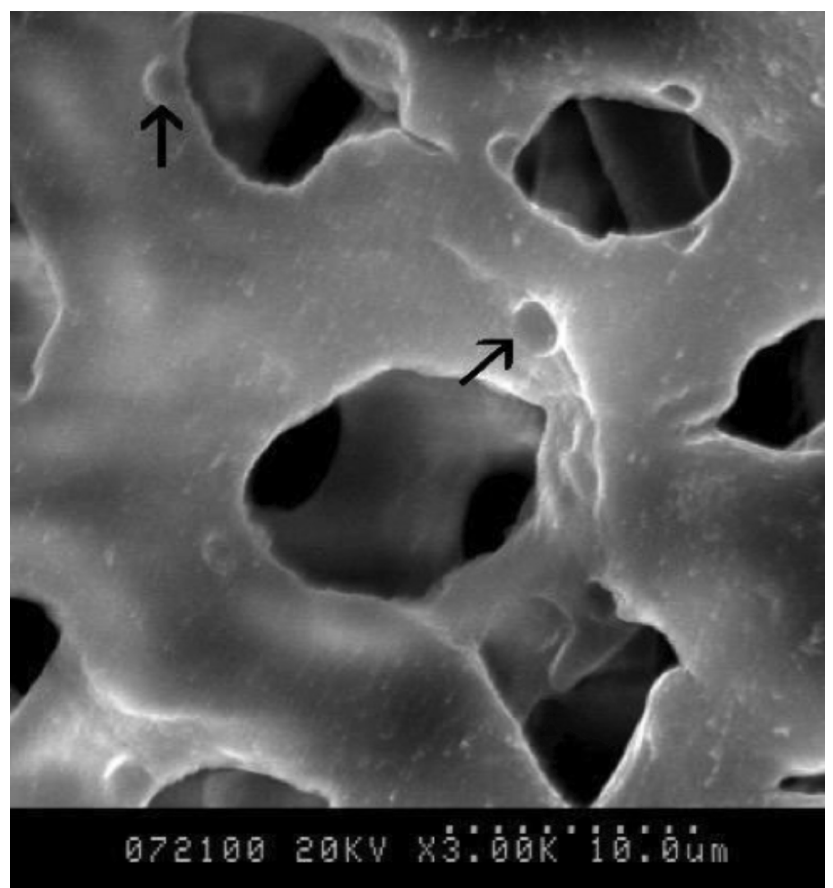

Fig. 8 The endothelial nuclei appeared on the surface of the alveolarcapillary casts. alveolar lumina. As the diameter of the alveolar capillary was larger than that of the mesh, the whole network was dense. Meanwhile, the meshes of the alveolar-capillary network in the superficial layer of the lung were looser than those of the deep layer. The meshes of the alveolar-capillary network were mainly oval and elliptical, and hexagonal, polygonal, and irregular meshes were also observed. The capillaries that organized the mesh network of the alveolar capillary were gently curved, and the edges were smooth.

\section{DISCUSSION}

Supply of alveolar capillary. There were different results regarding the supply of the alveolar capillary that have been studied in the pulmonary microvasculature of humans and mammals. A study by Ohtani (1980) explained that the pulmonary artery, after entering the lung, branched repeatedly to extend into the capillary. These capillaries communicated with one another to form a dense, reticular sheath-like alveolar capillary network around the alveolar wall and were drained by the branches of the pulmonary vein. Similarly, the present study found that the capillaries united with one another into a single layer of a dense network around the alveolus, and by contrast, the alveolar-capillary networks were arranged in honeycombed structures.

Guangqi et al. $(1981,1983)$ found that the alveolarcapillary network was supplied by the branches of the precapillary arteriole in dog lungs, while in humans and monkeys, Rui et al. reported that only the microvasculature was supplied by branches, which were formed by grades from the terminal arteriole to the precapillary arteriole. In monkeys, in addition to the branching of the pulmonary microvasculature, the terminal arteriole directly gave off capillary branches to unite with the alveolar-capillary network, which was different than in humans. Contrary to these results, the current research showed that the mesh density of the alveolar-capillary network in the pulmonary superficial layer was small in the deep layer, which was suggested to be a transitional phenomenon of the capillary network from loose to dense in the course of the subpleural capillary extending 
into the alveolar-capillary. Additionally, the capillary diameter was larger than that of the mesh; the capillary possessed a majority of proportions in the alveolar septum, which increased the capillary contact area, and the air in the alveolus was involved in gas exchange.

Studies reported by Binyou et al. (1990) showed that the supplied form of the alveolar-capillary network in the human lung could be divided into two classes: the terminal arteriole, which directly gave off the branches, was curved along the entrance of the alveolus and sent off capillaries during processing to form the alveolar-capillary network; another was the continuity from the subpleural or the interlobular septum capillary. However, the present report showed that the capillaries unite with each other into a single layer of a dense network around the alveolus.

Huiqin et al. (1988) observed that the alveolar capillary continued from the subpleural or the interlobular septum capillary in rats, which was similar to the findings of Guangqi et al. (1983). The pulmonary arteriole and the terminal arteriole gave off many branches during processing, and then the branches extended into precapillary arterioles to curve along the entrance of the alveolus and give off capillaries on their way. Similar to the current reported results, the alveolar capillary extended from the subpleural or the interlobular septum capillary. It was supplied directly by the capillary branches of the precapillary arteriole or the terminal arteriole.

By applying the replica scanning electron microscopic method, Yu \& Chongyang (1995), Yu \& Qibin (1996) and Yu et al. (1997b, 1998b) observed the threedimensional characteristics of the pulmonary microvasculature in laboratory rabbits, pikas, golden monkeys, and mice. Their results showed that the alveolar capillaries were not only continued from the subpleural or the interlobular septum capillary but were also supplied directly by the precapillary arteriole. The present study found that the resources of the alveolar capillary in the Bactrian camel lung were richer than those in these mammals. The alveolar capillaries in the Bactrian camel lung were not only extended from the subpleural or the interlobular septum capillaries, but were also supplied directly by the capillary branches of the precapillary arteriole or the terminal arteriole. Meanwhile, it was commonly observed that one alveolar capillary network was the environment. However, in the Bactrian camel, because of the rich supply forms of the alveolar capillary, the blood could be supplied in a compensatory manner from other branches to maintain normal blood circulation while blocking the microvasculature. Therefore, the diversity of the supply forms of the alveolarcapillary was suggested to be one of the adaptable structures in the Bactrian camel, which was found living in a drought conditions and hot environments for long periods of time.

The peculiar architecture of the alveolar-capillary network. By studying the histological characteristics of pulmonary tissue in the Bactrian camel, Jia et al. (1998) found that many alveoli collapsed in the lung. The study further explained that the respirational function was accomplished by the alveoli being plumped in normal conditions. For instance, running for a long period, a cataclysm of the environment can cause collapsed alveoli to be reactivated. Similarly, the current reports on the Bactrian camel found that there are many alveolar capillaries that shrank and caused the collapse of these alveoli. This proved the existence of the structures in the Bactrian camel lung from the angle of pulmonary microvasculature architecture. It was presumed that the lung in the Bactrian camel contains a high respirational potential, the alveoli in normal conditions were generally sufficient for respirational needs, and only the normal alveoli were insufficient due to cataclysm of the environment or strenuous exercise. The collapsed alveoli would be reactivated, which were likely to be the structural foundation of the respirational potential. Additionally, the redundant alveoli shrinking contributed to reducing the water consumption from lung in the normal condition of the Bactrian camel.

Kendall \& Eissmann, who studied pulmonary capillaries in humans, used a latex replication method and reported the presence of unbranched capillary vessels interconnected widely and separated with the alveolarcapillary rings, which were termed "interconnections." In contrast, the present research found a type of anastomosing branch connecting the alveolar capillary network adjacently, termed "Y-type anastomosing branches."

\section{CONCLUSION}

The study documented that there were many collapsed alveoli in the Bactrian camel lung, and the disproportionable pressure between the pulmonary alveoli induced an easy imbalance of the blood flow in the alveolar capillary and affected the efficiency of gas exchange. Therefore, the current research suggested that the function of the anastomosing capillary branch was likely to be regulating the flow of blood between the alveolar-capillary network, balancing the blood flow volume, and improving the gas exchange efficiency in pulmonary alveoli.

Data Availability. The analyzed data are provided in full in the results section of this manuscript. Raw data are available at DOI:10.6084/m9.figshare.11482887. 


\section{ACKNOWLEDGMENTS}

The authors are very grateful to the Natural Science Foundation of Gansu Province (Project Number: 17JR5RA142) and the Gansu Agricultural University Library Team for the financial and numerous assistance for granting the fund and collecting the references. This research could be impossible without assistance rendered. The funders played no role in the study design, data collection, and analysis, decision to publish, or preparation of the manuscript.

DU, X.; LIU, X. \& MAWOLO, J. B. Arquitectura de los capilares alveolares de pulmones de camellos bactrianos (Camelus bactrianus). Int. J. Morphol., 38(6):1779-1785x, 2020.

RESUMEN: El camello bactriano, es originario de China y Mongolia, es de gran tamaño y es una especie de ungulado de dedos pares. Las dobles jorobas del lomo del camello bactriano lo diferencian del dromedario, que tiene una sola joroba. Esta especie se ha adaptado a condiciones inadecuadas (falta de alimento y agua) en el desierto de Gobi y ha avanzado en características anatómicas y fisiológicas únicas durante un período de evolución prolongado. Se han realizado varios estudios sobre las características anatómicas del camello bactriano, pero ninguno ha prestado atención a los capilares alveolares del pulmón de este animal. Por lo tanto, el presente estudio tuvo como objetivo principal explorar la arquitectura del capilar alveolar en el pulmón del camello bactriano y explicar el mecanismo del flujo sanguíneo. A partir de nuestro trabajo se examinó la arquitectura del capilar alveolar en el pulmón del camello bactriano (Camelus bactrianus) mediante la realización de métodos de microscopía electrónica de barrido y escaneo pulmonar. Los informes mostraron que los recursos del alvéolo-capilar se originaban en los capilares del espacio subpleural o del tabique interlobulillar y a veces se originaban en las arteriolas precapilares o directamente en las arteriolas terminales. Los capilares alveolares se anastomosaban y formaban una densa red de capa única en forma de cesta que rodeaba el alvéolo. El diámetro del macerado de la red alveolarcapilar era mayor que el del capilar y el aspecto del macerado era ovalado y elíptico. Muchas de las redes alvéolo-capilares colapsadas se encontraron en la arquitectura microvascular alveolar en el pulmón del camello bactriano. El estudio encontró que, muchos alvéolos colapsados en el pulmón del camello bactriano, la presión desproporcionada entre los alvéolos pulmonares inducía un menor desequilibrio del flujo sanguíneo en el capilar alveolar, lo que afectaba la eficiencia del intercambio de gases. Por lo tanto, la función de la rama capilar anastomosante probablemente regularía el flujo sanguíneo entre la red alveolar-capilar.

PALABRAS ClaVE: Camello bactriano; Pulmón; Microscopía electrónica de barrido (SEM); Capilar alveolar; Flujo sanguíneo.

\section{REFERENCES}

Binyou, Z.; Yunpeng, Z.; Liubao, Z. \& Wenhui, G. Microvasculature of the human lung. Acta Anat. Sin., 21(3):233-8, 1990.

Buchacker, T.; Mühlfeld, C.; Wrede, C.; Wagner, W. L.; Beare, R.; McCormick, M. \& Grothausmann, R. Assessment of the alveolar capillary network in the postnatal mouse lung in 3D using serial block-face scanning electron microscopy. Front. Physiol., 10:1357, 2019.

Chaoyou, Z. SEM Atlas of Microvasculature Cast in Organs. Beijing, Beijing Science Press, 1988. pp.71-7.

Fujii, S.; Tamura, T. \& Okamoto, T. Microarchitecture of air capillaries and blood capillaries in the respiratory area of the hen's lung examined by scanning electron microscopy. Nihon Juigaku Zasshi, 43(1):83-8, 1981.

Guangqi, H.; Baolin, W. \& Chaoyou, Z. Observations of the dog pulmonary capillaries and alveolar casts under SEM. Acta Anat. Sin., 12(4):390-2, 1981

Guangqi, H.; Baolin, W. \& Rui, L. Observations of the human pulmonary capillaries and alveolar casts under the scanning electron microscope. Acta Anat. Sin., 14 (2):113-5, 1983

He, W.; Zhang, W.; Cheng, C.; Li, J.; Wu, X.; Li, M.; Chen, Z. \& Wang, W. The distributive and structural characteristics of bronchus-associated lymphoid tissue (BALT) in Bactrian camels (Camelus bactrianus). PeerJ, 7:e6571, 2019.

Hijiya, K. \& Okada, Y. Scanning electron microscope study of the cast of the pulmonary capillary vessels in rats. J. Electron Microsc. (Tokyo), 27(1):49-53, 1978.

Huiqin, S.; Yafei, Z.; Qihong, Z. \& Zun, Z. Observations of the rat pulmonary microvascular and alveolar casts under SEM. Acad. J. Second Mil. Med. Univ., 9(6):536-7, 1988

Jia, N.; Li, X. M. \& Chen, H. Structural characteristics of pulmonary tissue of Bactrian camel. Acta Vet. Zootech. Sin., 29(4):349-54, 1998.

Johnson, L.; Montgomery, J. B.; Schneider, J. P.; Townsend, H. G. G.; Ochs, M. \& Singh, B. Morphometric examination of the equine adult and foal lung. Anat. Rec. (Hoboken), 297(10):1950-62, 2014.

Kendall, M. W. \& Eissmann, E. Scanning electron microscopic examination of human pulonary capillaries using a latex replication method. Anat. Rec., 196(3):275-83, 1980.

Ohtani, O. Microvasculature of the rat lung as revealed by scanning electron microscopy of corrosion casts. Scan. Electron Microsc., (3):349-56, 1980.

Rui, L.; Guiqin, Y. \& Baolin, W. Three-dimensional architecture of organic microvascular in the human and the monkey. Beijing, Beijing Science Press, 1993. pp.69-73.

Smith, D. G. \& Campbell, G. The anatomy of the pulmonary vascular bed in the toad: Bufo marinus. Cell Tissue Res., 165(2):199-213, 1976.

Weibel, E. R. \& Gomez, D. M. Architecture of the human lung. Science, 137(3530):577$85,1962$.

West, N. H.; Bamford, O. S. \& Jones, D. R. A scanning electron microscope study of the microvasculature of the avian lung. Cell Tissue Res., 176(4):553-64, 1977.

Yu, S. \& Chongyang, L. Observation of the rabbit pulmonary capillaries and alveolar casts under the scanning electron microscope. J. Lanzhou Univ., 31:1-3, 1995.

Yu, S. \& Qibin, Y. Observation on pulmonary capillaries of Ochotona daurica under scanning electron microscope. Chin. J. Northwest Normal Univ., 32(4):115-7, 1996.

$\mathrm{Yu}, \mathrm{S}$. Observation of golden monkey (Rhinopithecus $R$. roxellanae) pulmonary capillaries and alveolar casts under the scanning electron microscopy. Acta Theriol. Sin., 17(4):301-2, 1997b

Yu, S. Observation of the mouse pulmonary capillary and alveolar casts under SEM Chin. J. Northwest Normal Univ., 34 (2):65-8, 1998 b.

Yu, S. SEM observation of the microvasculature casts. Acta Zool. Sin., 44(4):384-90, 1998a.

Yu, S. SEM observation on the lung microvasculature of the snake Coluber spinalis Acta Zool. Sin., 43(2):214-5, 1997a.

Yu, S.; Xiaohua, D.; Haiyan, L.; Jianlin, W. \& Ziren, W. Architecture of subpleural microvessel of the lung in Bactrian camel (Camelus Bactrianus). J. Camel Pract. Res., 11(1):27-34, 2004

Corresponding Author:

Xia Liu

Anning District

Lanzhou City

Gansu Province, 73000 People's

REPUBLIC OF CHINA

Received: 16-04-2020

Email: drdugau2019@gmail.com
Accepted: $11-07-2020$ 